\section{Responses of male mice to odors from stressed vs nonstressed males and females}

\author{
W. J. CARR, PAMELA ROTH, and MARYANNE AMORE \\ Beaver College, Glenside, $\mathrm{Pa} .19038$
}

Thirty-two male mice reared in social isolation from the time of weaning preferred the odor from nonshocked males over the odor from males which had received a single series of shocks shortly before the odors were collected. Twenty-six males preferred the odor from nonshocked females over that from shocked females.

In one or more species of rodent, odors emanating from an individual enable other rodents to respond discriminatively to the individual's location, species, strain, sex, level of development, state of sexual readiness, membership in one of several local groups, emotional state, and even its personal identity (Archer, 1968; Bronson, 1971; Calhoun, 1962 Gleason \& Reynierse, 1969; Wilson, 1968). Commonly referred to as pheromones, these olfactory stimuli are known to influence such social activities as aggregation, mating, parent-young interactions, and the agonistic behavior associated with territoriality and dominance hierarchies (Barnett, 1964; Ropartz, 1968; Whitten, 1966).

The present investigation is concerned with the reaction of mice to odors from stressed vs nonstressed conspecifics. Müller-Velten (1966) observed a flight reaction by house mice exposed to the odor from frightened males of the same species, but not to that from frightened conspecific females or from frightened males of two other species of mouse. He elicited the fear scent (Angstgeruch) by shaking, probing, or blowing on them. Carr, Martorano, \& Krames (1970) found that mice prefer the odor from nonstressed conspecifics over that from stressed conspecifics, the stressors being defeat in male-to-male combat or electric shock. More recently, Colyer (1971) demonstrated that the odor of shocked mice serves as a repellent to conspecifics, while the odor of nonshocked mice serves as an attractant. The tendency to flee from the fear scent may minimize exposure to predators and other potentially dangerous situations, while the tendency to approach the odor of nonstressed conspecifics may hold the local group together.

\section{EXPERIMENT 1}

Carr et al (1970) and Colyer (1971) used as stressed mice animals which earlier had received a series of shocks each day for 10-12 days. Moreover,
Colyer found that mice avoid the odor from such chronically stressed males, even though the latter have not been shocked for $24 \mathrm{~h}$ prior to the collection of the odors. Therefore, it is not clear whether the fear scent reflects only an enduring condition of chronically stressed mice or possibly a transitory condition of acutely stressed mice as well. If, in the natural setting, mice actually use the fear scent to avoid potentially dangerous but transient situations, then a single stressful event should elicit the fear scent and cause conspecifics to withdraw. To test this possibility, Experiment 1 was designed to determine the reaction of male mice to odors from stressed vs nonstressed males, the stressed animals having been exposed to a single $10 \cdot \mathrm{min}$ series of shocks just before the odors were collected.

\section{Method}

The Ss were 32 male mice of the C57BL/6J strain, obtained from the Jackson Laboratory. In addition, 32 male mice of the same strain and age served as odorant animals. Except as noted below, all animals were housed individually in cages measuring $8 \times 10 \times 10$ in. in an air-conditioned room maintained at $75^{\circ} \mathrm{F}$. They had constant access to Purina Lab Chow and water.

Apparatus and Procedure

When they were 11-12 weeks old, each $S$ received an odor preference test much like that described earlier (Carr et al, 1970). The test consisted of two 10-min periods separated by $48 \mathrm{~h}$. Testing was conducted in a cage measuring $10 \times 15 \times 28$ in.; the walls and ceiling were made of hardware cloth, and the floor was covered with clean sawdust. Located in the rear corners of the test cage were two cylindrical cardboard containers, measuring $4 \times 4.5$ in. One of these nonstressed mouse. Holes in the caps of each container allowed for the passage of odor-laden air from the containers into the test cage, but containers had previously housed a stressed mouse and the other a hardware cloth stapled over the holes prevented $S$ from entering the containers. A cylindrical cardboard sleeve, measuring $3 \times 4$ in., was attached to each container. The excelsior formed a barrier preventing Ss' seeing into the container; they spent considerable time pulling on the excelsior in an apparent attempt to enter the container. (For a detailed description of the apparatus, see Carr, Loeb, \& Dissinger, 1965, p. 371, Fig. 1.)

During the odor preference test, Es recorded the number of seconds Ss spent investigating the odor emanating from each container. An $\mathbf{S}$ was said to be investigating a container if any part of its body (less tail) extended inside the atrium attached to the container housing that odor. The Ss were said to prefer one odor over another if, as a group, they spent significantly more time investigating the former odor. A counterbalancing procedure was used to control for any possible position preference on the part of Ss.

The 32 male mice serving as odorant animals were treated as follows: Beginning 13 days before testing, the mice were handled for $1 \mathrm{~min}$ per day and for 10 days were housed individually for $11 \mathrm{~min}$ per day in shock boxes measuring $2.5 \times 5 \times 7$ in. Thus, these mice were habituated to the procedure. On the day of their testing, 14 mice were designated randomly as stressed odorant animals and received $201-\mathrm{mA}$ shocks of $5 \mathrm{sec}$ duration each. Shocks were delivered via a scrambler and generator of the matched-impedance constant-current design. One shock was delivered during each 30 -sec interval of the last $10 \mathrm{~min}$ spent in the box; within this constraint, the interval between shocks was random. The 14 remaining mice were designated as nonstressed odorant animals; they received identical treatment, except that they were housed in boxes in which no animal was ever shocked. Upon removal from the shock boxes, the odorant animals were housed for $1 \mathrm{~h}$ in the cardboard containers described above. They then were removed and the odor-laden containers were used in testing. Each mouse served only once as an odorant animal, and new containers and atria were used on each day of testing. The Ss and odorant animals were habituated to the containers by placing one in their home cages 4 days before testing began.

Finally, Ss were subdivided into seven lots of four or five mice each. During a test period, each lot reacted to a different pair of odorant animals. Thus, Ss' reactions to the test odors stemmed from that which distinguishes shocked from 
Table 1

Comparison of Time Spent Investigating Test Odors During 20-M in Test

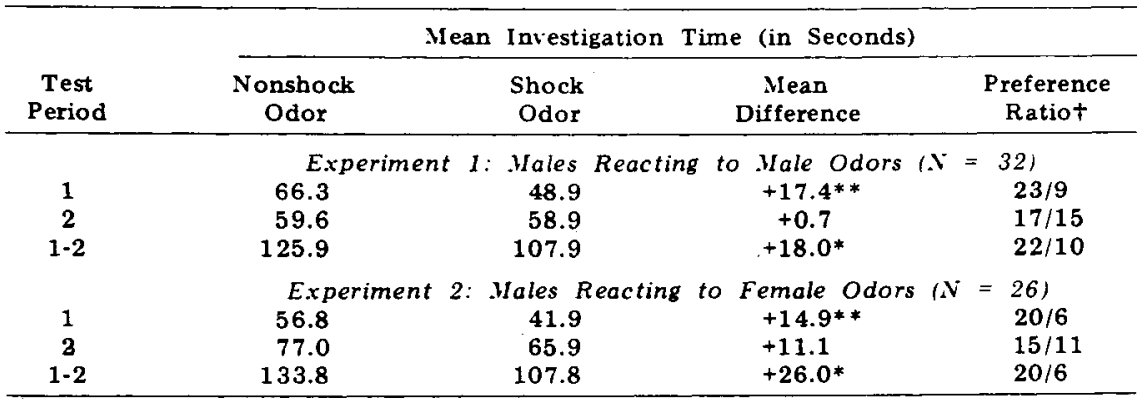

$\div$ See text for explanation: $* p<.05, * * p<.01$

nonshocked mice and not from odors peculiar to individuals.

\section{Results}

Table 1 shows the mean time male Ss spent investigating the odors from shocks vs nonshocked males for the two $10-\mathrm{min}$ test periods and for the 20-min test as a whole. The table also shows the mean difference scores (nonshock minus shock) and the preference ratios, i.e., the number of Ss spending the majority of their time with the odor of nonshocked mice divided by the number spending the majority of time with the odor of shocked mice.

The results indicated that male mice prefer the odor of nonshocked mice over that from shocked mice. The observed difference scores for the 20-min test as a whole departed significantly from chance expectancy (Wilcoxon matched-pairs signed-ranks test, $T=155, p<.05$ ), as did the observed difference scores for the first $10-\mathrm{min}$ test period ( $\mathrm{T}=113.5$, $\mathrm{p}<.01)$. The observed difference scores for the second $10-\mathrm{min}$ test period did not depart significantly from chance expectancy.

\section{EXPERIMENT 2}

Müller-Velten (1966) reported that both male and female mice exhibit a flight reaction in response to the odor of stressed males and that females respond similarly to the odor of stressed females. He also concluded that males exhibit no reliable flight reaction in response to the odor of stressed females, and he suggested that the aversive property of the female's fear scent may be offset by a sex attractant. However, Müller-Velten did not control for the ovarian condition of his females. Therefore, Experiment 2 was designed to determine the reaction of male mice to the odors of shocked vs nonshocked females, the females being equated for ovarian condition at the time the odors were collected.

\section{Method}

Using a procedure and apparatus identical to that used in Experiment 1, 26 male mice of the $\mathrm{C} 57 \mathrm{BL} / 6 \mathrm{~J}$ strain reacted to the odors from stressed vs nonstressed females. On each day of testing, approximately twice as many females as were needed received the series of shocks or the control series and then each was housed in a cardboard container for $1 \mathrm{~h}$. Upon removal from the containers, the ovarian condition of each female was ascertained via a vaginal smear. The odor used during testing came from females which were in either the diestrous or metestrous phase. Results

Shown in Table 1, the results of Experiment 2 indicated that male mice prefer the odor of nonshocked females over that from shocked females. The observed difference scores for the 20-min test as a whole departed significantly from chance expectancy $(\mathrm{T}=82, \mathrm{p}<.02)$, as did the observed difference scores for the first 10-min test period $(\mathrm{T}=54.5, \mathrm{p}<.01)$. The observed difference scores for the second 10-min test period did not differ significantly from chance expectancy.

The results of Experiment 1 indicated that male mice prefer the odor of nonshocked males over that from males receiving a single series of shocks shortly before the odors were collected. This finding confirms an earlier report (Carr et al, 1970) of a similar preference using chronically shocked males. The results of Experiment 2 indicated that male mice also prefer the odor of nonshocked females over that from shocked females, provided that the females are equated for ovarian condition at the time the odors are collected. Although additional sites may be involved, Müller-Velten (1966) believes that the fear scent is contained in the urine.

Colyer (1971) demonstrated that male mice are repelled by the odor from shocked males and attracted to the odor from nonshocked males. Coupled with Colyer's report, the present findings lend ecological validity (Brunswik, 1956) to the concept of a transient fear scent operating in mice. Emitted by both males and females, this fear scent can be elicited by a single stressful event. In the natural setting, their tendency to withdraw from sites possessing the fear scent of conspecifics may well protect mice from predators and other dangerous situations.

\section{REFERENCES}

ARCHER. J. The effect of strange male odor on aggressive behavior in male mice. Journal of Mammalogy, 1968, 49. $572-575$.

BARNETT, S. A. Social stress. In J. D Carthy and C. L. Duddington (Eds.), Viewpoints in biology. London: Butterworths, 1964.

BRONSON, F. H. Rodent pheromones. Biology of Reproduction. 1971 . (Supplement 3), in press.

BRUNSWIK. E. Perception and representative design of psychological experiments. Berkeley: University of Califormia Press, 1956

CALHOUN, J. B. The ecology and sociology of the Noruay rat. (USPHS Publication No. 1008), Washington, D.C: United States Government Printing Office, 1962.

CARR, W. J., LOEB, L. S., \& DISSINGER, M. L. Responses of rats to sex odors. Journal of Comparative \& Physiological Psychology, 1965, 58, 370-377.

CARR, W. J., MARTORANO, R. D. \& KRAMES, L. Responses of mice to odors associated with stress. Joumal of Comparative \& Physiological Psychology. $1970,71,223-228$

COLYER, S. W. Valence of stress and nonstress indexing odors and the effectiveness of post stress odor emission in mice. Unpublished doctoral dissertation. Temple University, 1971.

GLEASON, K. K., \& REYNIERSE, J. H The behavioral significance of pheromones in vertebrates. Psy chological Bulletin, 1969, 71, 58-73.

MÚLLER-VELTEN, H. Über den Angstgeruch bei der Hausmaus. (.Mus musculus L.). Zeitschrift für Vergleichende Physiologie, 1966, 52. 401-429.

ROPARTZ, P. The relation between olfactory stimulation and aggressive behaviour in mice. Animal Behaviour, 1968, 16, 97-100.

WHITTEN. $W$. $K$. Pheromones and mammalian reproduction. Recent Advances in Reproductive Physiology, $1966,1,155-177$

WILSON, E. O. Chemical systems. In T. A. Sebeok (Ed.). Animal communcation. Bloomington: Indiana University Press. 1968. 